\title{
Contribution of Forest Species to the Floristic Composition of a Forested Savanna in Southeastern Brazil
}

\author{
Marcelo Henrique Ongaro Pinheiro ${ }^{*}$ and Reinaldo Monteiro \\ Universidade Estadual Paulista; Instituto de Biociências; Departamento de Botânica, Av. 24-A, n. 1515; \\ mhop@rc.unesp.br; reimonte@rc.unesp.br; 13506-900; Rio Claro - SP - Brasil
}

\begin{abstract}
Based on studies of floristic lists the contribution of forest tree and shrub species in a forested savanna area in the city of Bauru, State of São Paulo, and in 14 different places sheltering cerrado sensu stricto and cerradão in Brazil is defined as the evidence of forest species causing a change of cerrado heterogeneity. The percentages of occurrence of forest species in the locations analyzed varied from zero to $4.5 \%$. The proximity of different forest matrices, the occurrence of fires and the inclusion criteria used were some of the factors that may have influenced such variation.
\end{abstract}

Key words: Ecotone, generalist species, exchange of floristic elements, facilitation, microhabitats

\section{INTRODUCTION}

Cerradões, or forested savannas, a terminology defined and used by Veloso (1992), widely occur in the cerrado biome and are, in the Brazilian vegetation system, often associated with transitions between the latter and seasonal semideciduous forests (Oliveira-Filho and Ratter, 2002). A discontinuous merging between the savannas and seasonal forests is also frequent along ecotonal areas (Leitão Filho, 1982), where the cerrado biome shows a greater floristic affinity with this forest phytocenosis than with ombrophilous forests (Méio et al., 2003). Exchanges of floristic elements among savanna formations and Atlantic and Amazonian forests possibly have been occurring since the Quaternary (Ab'Sáber, 2003) and have been facilitated by such access paths as gallery forests (Rizzini, 1997). It has been said that more than half of the flora of central Brazil savanna originates from other types of vegetation (Rizzini, 1971). Therefore, the heterogeneity of the cerrado flora is thus influenced by the proximity of different forest phytocenoses (Rizzini, 1997). In a comprehensive floristic comparison of the Central Brazilian savannas then known, Rizzini (1971) concluded that more than half of their species came from other plant formations.

Different abiotic factors, such as wateravailability (Silberbauer-Gottsberger and Gottsberger, 1984), humidity and edaphic fertility (Durigan et al., 2003) and the action of fires (Coutinho, 1990) may influence the definition of the local floristic composition in savanna formations (Coutinho, 1978; Braithwaite, 1996; Miranda et al., 2002). Besides these facts, frosts can also be considered, but they are climatic phenomena almost absent in most of Brazil (Cavassan, 2002), and may affect plant species in different manners (Silberbauer-Gottsberger et al., 1977).

\footnotetext{
* Author for correspondence
} 
In regions where anthropic intervention has been suppressed or diminished, especially through the absence of fires, savanna areas begin to present secondary succession, manifested by an increase in local vegetation cover and density and an enrichment of the floristic composition due to the immigration of species sensitive to the effects of fires (Henriques and Hay, 2002), especially forest species (Hopkins, 1992). The present work aimed at analyzing the influence of the seasonal semideciduous forest on the floristic composition of a forested savanna located in Southeastern Brazil, close to the southern limit where savanna formations occured. It also aimed to compare the influence of forest species on the forested savanna studied and in other savanna formations from other Brazilian locations, using some hypotheses to explain why forest species have colonized areas of savanna phytocenoses, and the expansion of forest formations into areas once occupied by cerrados.

\section{MATERIALS AND METHODS}

Characterization of the area of study: Located in the district of Bauru, in the center-west of the State of São Paulo, the Municipal Botanical Garden of Bauru (JBMB, with center geographic coordinates $22^{\circ} 20^{\prime} \mathrm{S}$ and $49^{\circ} 00^{\prime} \mathrm{W}$ ), is situated to the southeast of the urban perimeter (Bauru, 1997). Its 321.71 ha area of native vegetation are mainly covered with forested savanna (circa 277 ha), but also include a seasonal semi-deciduous forest (12 ha) and a remnant of hygrophyllous forest (1 ha) restricted to a small area close to the Vargem Limpa creek (Fig. 1), which crosses the JBMB (Pinheiro et al., 2002).

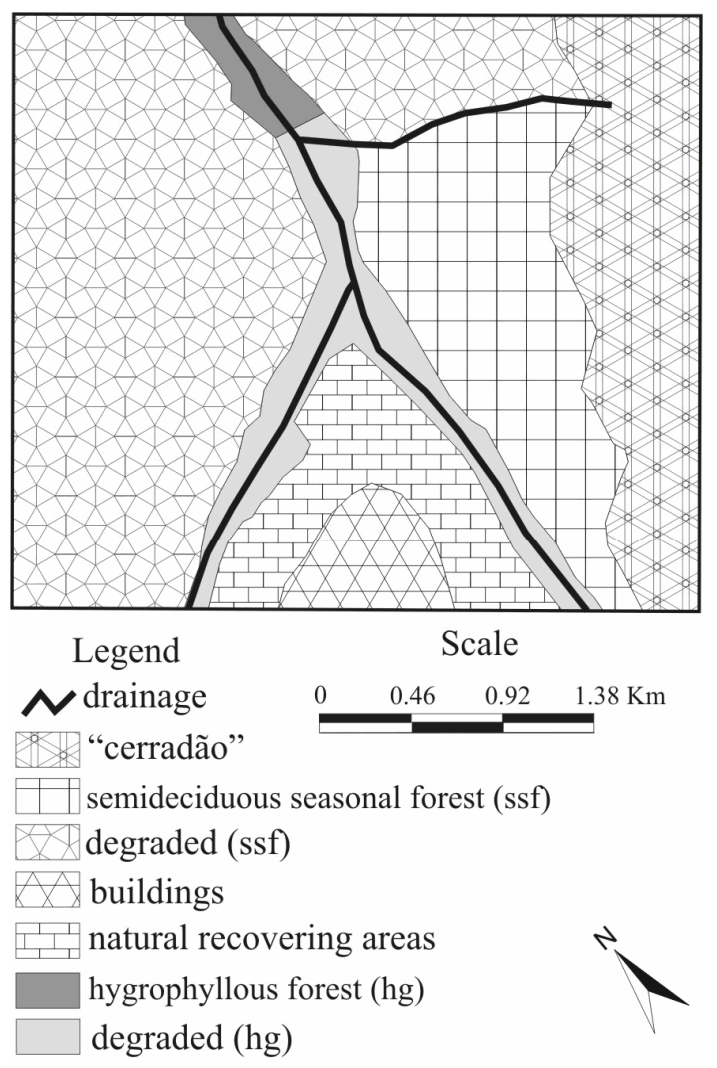

Figure 1 - Distribution of vegetation in JBMB, Bauru, Brazil

Some parts of the area were deforested and burnt in the past. The last major fire happened in 1994 which, added to others that occurred before left its vestiges still found today in some small areas of the forested savanna and on the border of the seasonal forest. The JBMB borders on estates as the registered areas of the UNESP campus, 90 ha, and that of the Instituto Lauro de Souza Lima, 217 ha, where forested savanna prevails (Pinheiro, 2000). Further information on the history of the 
area of study and the JBMB, such as soil features, climate and vegetation can be found in Pinheiro et al. (2002).

Methodology: The collection of botanical material from tree and shrub species took place with random walks and, although concentrated in the savanna forest, i.e., close to the area of transition with the contiguous seasonal semi-deciduous forest, they also occurred within the interior of the seasonal forest. After taxonomically identified based on comparisons in herbaria, and through consultations to specialists and bibliography, complete collections of the sampled species were deposited at the HRCB and UEC herbaria (Universidade Estadual Paulista at Rio Claro, and Universidade Estadual de Campinas, respectively). These species were organized into a floristic list, according to their families, genera and collection numbers, as occurring at least in the forested savanna, or in both phytocenoses ( forested savanna and seasonal semi-deciduous forest, Table 1). The correct spelling of the scientific names and of the abbreviations of the different authors' names were looked up in the International Plant Names Index, (www.ipni.org) and the W3TROPICOS (www.mobot.org) databank.

The analyses of the exchanges of floristic elements were limited to determining the occurrence of forest species within the forested savanna. The species database were the lists found in Goodland (1970), Rizzini (1971), Heringer et al. (1977), Leitão Filho (1992), Mendonça et al. (1998), Castro et al. (1999), Ratter et al. (2000), Ratter et al. (2003) and Durigan et al. (2004). In addition, information from the Foundation André Tosello database (www.bdt.fat.org.br) and a floristic report contained in the Resolução SMA 47/03, that guides the practices of mixed reforestation in degraded areas (Barbosa, 2004) were also used to characterize the species found in the JBMB for their the ability to occupy different habitats as specialist or generalist (Table 1). Following the concepts used by Rizzini (1971), the taxa here sampled were defined as peculiar to forest formations when not reported as savanna species in the above mentioned sources. Thus, since they could be considered as accessory to the savannas (Rizzini, 1971), the generalist species were not included.

Floristic lists of species found in riverine forests (Silva Júnior et al., 1998; Rodrigues and Nave, 2000; Felfili et al., 2001; Silva Júnior et al., 2001) were used to define whether the species considered peculiar to forest formations could also be found close to waterways.

An analysis of the occurrence of plant species uncharacteristic of savanna formations coming from forest phytocenoses in 14 other areas from the States of São Paulo, Paraná, Minas Gerais, Mato Grosso and Distrito Federal (Ferracini et al., 1983; Pagano et al., 1989; Toledo Filho et al., 1989; Felfili et al., 1993; Durigan et al., 1994; Bicudo et al., 1996; Paschoal and Montanholi, 1997; Uhlmann et al., 1998; Araújo et al., 1999; Durigan et al., 1999; Batalha and Mantovani, 2001; Costa and Araújo, 2001; Durigan et al., 2002; Felfili et al., 2002) was carried out. The results obtained and methodological features used in these areas were compared to those of the present study. The different analyses involving taxa coming from forest formations considered only thosetree and shrub species that could not be included in the group of the characteristic or accessory species of savanna formations, as defined according to the lists here used.

\section{RESULTS}

A total of 135 species belonging to 53 families were found, out of which 70 species were found only in the forested savanna and 65 in both phytocenoses (Table 1), i.e., in the forested savanna and in the seasonal semi-deciduous forest. Of the nine families richest in species (Rubiaceae, with 11, Mimosaceae 10, Asteraceae, Malpighiaceae and Myrtaceae with 9 each, and Caesalpiniaceae, Erythroxylaceae, Verbenaceae and Vochysiaceae with 5 each) in the forested savanna of JBMB, Mimosaceae presented one species peculiar to forest formations, Inga marginata, which occured in both riverine and gallery forests (Rodrigues and Nave, 2000; Silva Júnior et al.,2001). Of the total of the tree and shrub species found in the JBMB, 4 were not mentioned by the works used as a reference: Cecropia catarinensis, Eupatorium inulaefolium, Faramea latifolia and Heteropteris pannosa; 6 were defined as characteristic from forest formations: Cestrum pedicellatum, Dalbergia frutescens, Inga marginata, Psychotria capitata, Stylogyne ambigua and Guapira hirsuta, of which only C. pedicellatum and G.hirsuta could not be found in gallery or riverine forests. 
Table 1 - Tree and shrub species of JBMB, Bauru, Brazil. Ecological occurences: generalists - ${ }^{1}$; savannic - ${ }^{2}$; humid savanna $-{ }^{3}$; Forest $-{ }^{4}$; humid forest $-{ }^{5}$; unspecific $-{ }^{6}$. NC - collector's number; FT - phytocenoses (C - forested savanna; F/C - semideciduous forest and C).

\begin{tabular}{|c|c|c|c|c|c|}
\hline Families/Species & NC & FT & Families/Species & $\mathrm{NC}$ & FT \\
\hline Arecaceae & & & $\begin{array}{l}\text { Gochnatia polymorpha } \\
\text { (Less.)Cabrera }\end{array}$ & $491 / 242$ & $\mathrm{~F} / \mathrm{C}$ \\
\hline Syagrus flexuosa (Mart.)Becc. ${ }^{2}$ & $466 / 494$ & $\mathrm{~F} / \mathrm{C}$ & Vernonia brasiliana (L.)Druce ${ }^{2}$ & 378 & $\mathrm{C}$ \\
\hline Anacardiaceae & & & Vernonia polyanthes Less. ${ }^{1}$ & 405 & $\mathrm{C}$ \\
\hline Tapirira guianensis Aubl. ${ }^{1}$ & $166 / 188$ & $\mathrm{~F} / \mathrm{C}$ & $\begin{array}{l}\text { Vernonia rubriramea } \\
\text { Mart.exDC }^{2}\end{array}$ & 285 & $\mathrm{C}$ \\
\hline Annonaceae & & & Bignoniaceae & & \\
\hline Annona coriacea Mart. $^{2}$ & $609 / 774$ & $\mathrm{~F} / \mathrm{C}$ & $\begin{array}{l}\text { Anemopaegma arvense (Vell.) } \\
\text { Stellfeld ex de Souza }\end{array}$ & 579 & $\mathrm{C}$ \\
\hline Xylopia aromatica (Lam.)Mart. ${ }^{2}$ & $59 / 527$ & $\mathrm{~F} / \mathrm{C}$ & Cybistax antisyphilitica Mart. $^{1}$ & 594 & $\mathrm{C}$ \\
\hline Apocynaceae & & & $\begin{array}{l}\text { Tabebuia aurea BenthandHook f } \\
\text { exS.Moore }\end{array}$ & 397 & $\mathrm{C}$ \\
\hline $\begin{array}{l}\text { Himatanthus obovatus } \\
\text { (Müll.Arg.)Woodson }{ }^{1}\end{array}$ & 649 & $\mathrm{C}$ & $\begin{array}{l}\text { Tabebuia ochracea } \\
\text { (Cham.)Standl. }{ }^{1} \text { subsp. ochracea }\end{array}$ & $518 / 535$ & $\mathrm{~F} / \mathrm{C}$ \\
\hline Tabernaemontana hystrix Steud. ${ }^{1}$ & $379 / 457$ & $\mathrm{~F} / \mathrm{C}$ & 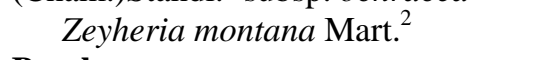 & 287 & $\mathrm{C}$ \\
\hline Aquifoliaceae & & & Bombacaceae & & \\
\hline Ilex affinis Gardn. ${ }^{3}$ & 623 & $\mathrm{C}$ & $\begin{array}{l}\text { Eriotheca gracilipes } \\
\text { (K.Schum.)A.Robyns } 1\end{array}$ & $350 / 801$ & $\mathrm{~F} / \mathrm{C}$ \\
\hline Araliaceae & & & Boraginaceae & & \\
\hline $\begin{array}{l}\text { Dendropanax cuneatum } \\
\text { (DC.)DecneandPlanch. }{ }^{1}\end{array}$ & $361 / 569$ & $\mathrm{~F} / \mathrm{C}$ & Cordia sellowiana Cham $^{1}$ & $381 / 389$ & $\mathrm{~F} / \mathrm{C}$ \\
\hline $\begin{array}{c}\text { Didymopanax vinosum } \\
\text { (Cham.andSchlecht.)March. }\end{array}$ & $182 / 307$ & $\mathrm{~F} / \mathrm{C}$ & Burseraceae & & \\
\hline Asteraceae & & & Protium heptaphyllum March. ${ }^{1}$ & $231 / 441$ & $\mathrm{~F} / \mathrm{C}$ \\
\hline Achyrocline satureioides DC. ${ }^{3}$ & 742 & $\mathrm{C}$ & Caesalpiniaceae & & \\
\hline Baccharis dracunculifolia DC. ${ }^{1}$ & 747 & $\mathrm{C}$ & $\begin{array}{l}\text { Bauhinia holophylla } \\
\text { (Bong.)Steud. }^{2}\end{array}$ & $215 / 844$ & $\mathrm{~F} / \mathrm{C}$ \\
\hline Eupatorium inulaefolium Kunth ${ }^{6}$ & 299 & $\mathrm{C}$ & Bauhinia ungulata L. $^{2}$ & 214 & $\mathrm{C}$ \\
\hline Gochnatia barrosii Cabrera ${ }^{2}$ & 365 & $\mathrm{C}$ & Lacistemaceae & & \\
\hline Copaifera langsdorffii Desf. ${ }^{1}$ & $524 / 585$ & $\mathrm{~F} / \mathrm{C}$ & 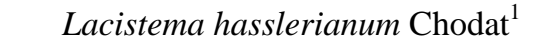 & $193 / 483$ & $\mathrm{~F} / \mathrm{C}$ \\
\hline Dimorphandra mollis Benth. ${ }^{2}$ & 380 & $\mathrm{C}$ & Lauraceae & & \\
\hline Hymenaea stigonocarpa Mart.ex & 628 & $\mathrm{C}$ & Ocotea corymbosa $\mathrm{Mez}^{1}$ & $233 / 247$ & $\mathrm{~F} / \mathrm{C}$ \\
\hline Hayne $^{2}$ & & & & & \\
\hline $\begin{array}{l}\text { Senna rugosa }(\mathrm{G} . \\
\text { Don.)H.S.Irwin.andBarneby }{ }^{2}\end{array}$ & 354 & $\mathrm{C}$ & Ocotea pulchella Mart. ${ }^{1}$ & $161 / 616$ & $\mathrm{~F} / \mathrm{C}$ \\
\hline $\begin{array}{l}\text { Caryocaraceae } \\
\quad \text { Caryocar brasiliense St.Hil. }\end{array}$ & 461 & $\mathrm{C}$ & $\begin{array}{l}\text { Ocotea velloziana (Meisn.) } \mathrm{Mez}^{1} \\
\text { Lvthraceae }\end{array}$ & $108 / 137$ & $\mathrm{~F} / \mathrm{C}$ \\
\hline Cecropiaceae & & & Lafoensia pacari St.Hil. ${ }^{1}$ & 221 & $\mathrm{C}$ \\
\hline Cecropia catarinensis Cuatrec $^{6}$ & 284 & $\mathrm{C}$ & Malpighiaceae & & \\
\hline Celastraceae & & & $\begin{array}{l}\text { Banisteriopsis malifolia (Nees } \\
\text { and Mart.)B.Gates }{ }^{2} \text { var.malifolia }\end{array}$ & 659 & $\mathrm{C}$ \\
\hline $\begin{array}{l}\text { Austroplenckia populnea } \\
\text { (Reissek ex Mart.)Ludell }{ }^{2}\end{array}$ & 595 & $\mathrm{C}$ & $\begin{array}{l}\text { Banisteriopsis variabilis } \\
\text { B.Gates }\end{array}$ & 286 & $\mathrm{C}$ \\
\hline Clusiaceae & & & Byrsonima basiloba A.Juss. $^{2}$ & 290 & $\mathrm{C}$ \\
\hline Kielmeyera rubriflora Cambess. ${ }^{2}$ & 276 & $\mathrm{C}$ & $\begin{array}{l}\text { Byrsonima coccolobifolia } \\
\text { H.B.andK. }\end{array}$ & 537 & $\mathrm{C}$ \\
\hline Cochlospermaceae & & & Byrsonima crassa Niedenzu $^{2}$ & 402 & $\mathrm{C}$ \\
\hline Cochlospermum regium Pilg. ${ }^{2}$ & 398 & $\mathrm{C}$ & Byrsonima intermedia A.Juss. ${ }^{1}$ & 189 & $\mathrm{C}$ \\
\hline Combretaceae & & & $\begin{array}{l}\text { Byrsonima verbascifolia } \text { Rich.ex } \\
\text { Juss. }\end{array}$ & 257 & $\mathrm{C}$ \\
\hline Terminalia argentea Mart. $^{1}$ & 523 & $\mathrm{C}$ & $\begin{array}{l}\text { Heteropteris byrsonimifolia } \\
\text { Juss. }^{2}\end{array}$ & 401 & $\mathrm{C}$ \\
\hline Terminalia glabrescens Mart. $^{1}$ & 391 & $\mathrm{C}$ & Heteropteris pannosa Griseb. $^{6}$ & 302 & $\mathrm{C}$ \\
\hline
\end{tabular}


Cont. Table 1

\begin{tabular}{|c|c|c|}
\hline Families/Species & NC & FT \\
\hline \multicolumn{3}{|l|}{ Connaraceae } \\
\hline Connarus suberosus Planch. ${ }^{2}$ & $479 / 608$ & $\mathrm{~F} / \mathrm{C}$ \\
\hline \multicolumn{3}{|l|}{ Dilleniaceae } \\
\hline Davilla elliptica St.Hil $^{2}$ & 410 & $\mathrm{C}$ \\
\hline Erythroxylum cuneifolium & 543 & $\mathrm{C}$ \\
\hline \multicolumn{3}{|l|}{ (Mart.)O.E.Schulz ${ }^{1}$} \\
\hline Erythroxylum pelleterianum & $129 / 545$ & $\mathrm{~F} / \mathrm{C}$ \\
\hline \multicolumn{3}{|l|}{ A.St.Hil. ${ }^{1}$} \\
\hline Erythroxylum suberosum & 463 & $\mathrm{C}$ \\
\hline \multicolumn{3}{|l|}{ A.St.Hil. ${ }^{2}$} \\
\hline Erythroxylum tortuosum Mart. ${ }^{2}$ & 476 & $\mathrm{C}$ \\
\hline \multicolumn{3}{|l|}{ Euphorbiaceae } \\
\hline Croton campestris A. St.Hil ${ }^{2}$ & 661 & $\mathrm{C}$ \\
\hline Croton floribundus Spreng. ${ }^{1}$ & 9177 & $\mathrm{~F} / \mathrm{C}$ \\
\hline Manihot tripartita Müll. Arg. ${ }^{2}$ & 190 & $\mathrm{C}$ \\
\hline Pera glabrata Poepp. ex Baill. ${ }^{1}$ & $249 / 289$ & $\mathrm{~F} / \mathrm{C}$ \\
\hline \multicolumn{3}{|l|}{ Fabaceae } \\
\hline $\begin{array}{l}\text { Acosmium subelegans } \\
\text { (Mohlenbr.) Yakovlev }\end{array}$ & 211 & $\mathrm{C}$ \\
\hline Bowdichia virgilioides & 226 & $\mathrm{C}$ \\
\hline H.B.andK. ${ }^{1}$ & & \\
\hline Dalbergia frutescens (Vell.) & 429 & $\mathrm{C}$ \\
\hline \multicolumn{3}{|l|}{ Britton $^{5}$} \\
\hline Platypodium elegans Vog. ${ }^{1}$ & $174 / 176$ & $\mathrm{~F} / \mathrm{C}$ \\
\hline \multicolumn{3}{|l|}{ Flacourtiaceae } \\
\hline Casearia sylvestris $\mathrm{Sw}{ }^{1}$ & $74 / 473$ & $\mathrm{~F} / \mathrm{C}$ \\
\hline Ficus asparzusa Casar. ${ }^{1}$ & $154 / 232$ & $\mathrm{~F} / \mathrm{C}$ \\
\hline Ficus guaranitica Chodat ex & 84 & $\mathrm{C}$ \\
\hline \multicolumn{3}{|l|}{ Chod. and Visher ${ }^{1}$} \\
\hline \multicolumn{3}{|l|}{ Myrsinaceae } \\
\hline Rapanea umbellata (Mart.) $\mathrm{Mez}^{1}$ & $371 / 478$ & $\mathrm{~F} / \mathrm{C}$ \\
\hline Stylogyne ambigua (Mart.) $\mathrm{Mez}^{5}$ & $259 / 283$ & $\mathrm{~F} / \mathrm{C}$ \\
\hline \multicolumn{3}{|l|}{ Myrtaceae } \\
\hline Campomanesia pubescens & 484 & $\mathrm{C}$ \\
\hline \multicolumn{3}{|l|}{ O.Berg. 1} \\
\hline Eugenia aurata O.Berg2 & $550 / 558$ & $\mathrm{~F} / \mathrm{C}$ \\
\hline Eugenia bimarginata DC. ${ }^{3}$ & 352 & $\mathrm{C}$ \\
\hline Myrcia albo-tomentosa DC. ${ }^{1}$ & 789 & $\mathrm{C}$ \\
\hline Myrcia bella Cambess. ${ }^{3}$ & 428 & $\mathrm{C}$ \\
\hline Myrcia lingua (O.Berg)Mattos ${ }^{2}$ & 392 & $\mathrm{C}$ \\
\hline Myrcia rhodeosepala Kiaersk. ${ }^{2}$ & $220 / 848$ & $\mathrm{~F} / \mathrm{C}$ \\
\hline Myrcia tomentosa Glaz. ${ }^{1}$ & $77 / 171$ & $\mathrm{~F} / \mathrm{C}$ \\
\hline Psidium guineense Pers. ${ }^{2}$ & 553 & $\mathrm{C}$ \\
\hline Nyctaginaceae & & \\
\hline $\begin{array}{l}\text { Guapira areolata } \\
\text { (Heimerl)Lundell }{ }^{2}\end{array}$ & 196 & $\mathrm{C}$ \\
\hline
\end{tabular}

\begin{tabular}{lcc}
\hline Families/Species & NC & FT \\
\hline Melastomataceae & & \\
$\quad \begin{array}{l}\text { Miconia albicans } \text { (Sw.) Steud. } \\
\text { Miconia stenostachya } \text { DC. }^{2}\end{array}$ & $134 / 425$ & F/C \\
$\begin{array}{l}\text { Tibouchina stenocarpa } \text { Cogn. }^{1} \\
\text { Meliaceae }\end{array}$ & $263 / 369$ & F/C \\
$\begin{array}{ll}\text { Trichilia pallida } \text { Sw. } \\
\end{array}$ & & C \\
& $262 / 278$ & F/C
\end{tabular}

\section{Mimosaceae}

\begin{tabular}{|c|c|c|}
\hline $\begin{array}{l}\text { Anadenanthera falcata (Benth.) } \\
\text { ( } 1\end{array}$ & 396 & $\mathrm{C}$ \\
\hline Calliandra parviflora Benth. ${ }^{2}$ & 191 & $\mathrm{C}$ \\
\hline Enterolobium contortisiliquum & 404 & $\mathrm{C}$ \\
\hline Morong. ${ }^{1}$ & & \\
\hline $\begin{array}{l}\text { Enterolobium gummiferum } \\
\text { Macbride }^{2}\end{array}$ & 400 & $\mathrm{C}$ \\
\hline Inga marginata Willd. ${ }^{5}$ & $113 / 241$ & $\mathrm{~F} / \mathrm{C}$ \\
\hline $\begin{array}{l}\text { Inga vera Willd. subesp affinis } \\
\text { (DC.)T.D. Penn. }\end{array}$ & $148 / 386$ & $\mathrm{~F} / \mathrm{C}$ \\
\hline Plathymenia reticulata Benth. ${ }^{2}$ & $295 / 846$ & $\mathrm{~F} / \mathrm{C}$ \\
\hline $\begin{array}{l}\text { Stryphnodendron adstringens } \\
\text { (Mart.) Coville }{ }^{2}\end{array}$ & 803 & $\mathrm{C}$ \\
\hline Stryphnodendron obovatum & 217 & $\mathrm{C}$ \\
\hline
\end{tabular}

Benth. $^{2}$

\section{Monimiaceae}

Siparuna guianensis Aubl. ${ }^{1}$

$219 / 442 \quad F / C$

\section{Moraceae}

Brosimum gaudichaudii Trécul ${ }^{1}$

Guettarda viburnoides Cham. and Schltdl. ${ }^{1}$

Palicourea rigida H.BandK. ${ }^{2}$

Psychotria capitata

RuizandPav. ${ }^{5}$

Psychotria carthagenensis Jacq. ${ }^{1}$

Rudgea viburnoides Benth. ${ }^{2}$

Tocoyena formosa K.Schum. ${ }^{2}$

\section{Rutaceae}

$157 \quad \mathrm{C}$

274/670 F/C

$548 \quad \mathrm{C}$

179/501 F/C

$192 / 323 \quad \mathrm{~F} / \mathrm{C}$

$356 / 849 \quad \mathrm{~F} / \mathrm{C}$

218 C

Zanthoxylum riedelianum Engl. ${ }^{1} \quad$ 467/664 F/C

\section{Sapindaceae}

Serjania erecta Radlk. $^{2}$

$643 \quad \mathrm{C}$

Solanaceae

Cestrum pedicellatum Sendtn. ${ }^{4}$

Cestrum sendtnerianum

Mart.exSendtn. ${ }^{1}$

Solanum granuloso-leprosum

Dunal $^{1}$

Solanum paniculatum L. $^{1}$

$465 \quad \mathrm{C}$

$131 / 258 \quad$ F/C

$773 \quad \mathrm{C}$

206/603 F/C

Sterculiaceae

Guazuma ulmifolia Lam. ${ }^{1}$

456/586 F/C 
Cont. Table 1

\begin{tabular}{|c|c|c|}
\hline Families/Species & NC & FT \\
\hline $\begin{array}{l}\text { Guapira gracilliflora } \\
\text { (Mart.ex.J.A.Schmidt.)Lundell }{ }^{2}\end{array}$ & 546 & $\mathrm{C}$ \\
\hline $\begin{array}{l}\text { Guapira hirsuta } \\
\text { (Choisy)Lundell }{ }^{4}\end{array}$ & $209 / 497$ & $\mathrm{~F} / \mathrm{C}$ \\
\hline Ochnaceae & & \\
\hline Ouratea spectabilis Engl. ${ }^{2}$ & 474 & $\mathrm{C}$ \\
\hline Polygonaceae & & \\
\hline $\begin{array}{l}\text { Coccoloba mollis Casar. }{ }^{1} \\
\text { Proteaceae }\end{array}$ & $144 / 563$ & $\mathrm{~F} / \mathrm{C}$ \\
\hline Roupala montana Aubl. ${ }^{1}$ & $487 / 606$ & $\mathrm{~F} / \mathrm{C}$ \\
\hline $\begin{array}{l}\text { Rhamnaceae } \\
\quad \text { Rhamnidium elaeocarpum } \\
\text { Reiss. }^{1}\end{array}$ & $245 / 251$ & $\mathrm{~F} / \mathrm{C}$ \\
\hline $\begin{array}{l}\text { Rubiaceae } \\
\text { Alibertia macrophylla } \\
\text { K.Schum. }{ }^{2}\end{array}$ & $132 / 172$ & $\mathrm{~F} / \mathrm{C}$ \\
\hline Chomelia pohliana Müll.Arg. ${ }^{\mathbf{1}}$ & $249 / 632$ & $\mathrm{~F} / \mathrm{C}$ \\
\hline $\begin{array}{l}\text { Coussarea hydrangeaefolia } \\
\text { Benth.andHook.f. }{ }^{1}\end{array}$ & $156 / 288$ & $\mathrm{~F} / \mathrm{C}$ \\
\hline $\begin{array}{l}\text { Faramea latifolia (Cham. and } \\
\text { Schltdl.)DC. }\end{array}$ & $159 / 250$ & $\mathrm{~F} / \mathrm{C}$ \\
\hline
\end{tabular}

Of the tree and shrub species found in JBMB that occurred both in the seasonal forest and the forested savanna, some could be defined as generalists for their capacity of occurring in different habitats, e.g., Casearia sylvestris, Copaifera langsdorffii, Siparuna guianensis and Trichilia pallida (Barbosa, 2004), and others could be considered characteristic of savanna formations, that is, specialists of these formations, e.g., Annona coriacea, Miconia albicans and Vochysia tucanorum, which were also found in both phytocenoses (Table 1).

The number of species characteristic of forest formations as a ratio of the total number of species in areas occupied by cerrado in different regions of Brazil and in the area of study gave percentages of occurrence varying between zero and $4.5 \%$ (Table 2 ). The highest percentage was found in the cerradão of the JBMB and in the cerrado s.s. of Agudos (Paschoal and Montanholi, 1997), followed by the forested savanna of Uberlândia (3.2\%) (Costa and Araújo, 2001). As for the possibility of the species defined as characteristic

\begin{tabular}{|c|c|c|}
\hline Families/Species & NC & FT \\
\hline \multicolumn{3}{|l|}{ Styracaceae } \\
\hline Styrax camporum Pohl $^{1}$ & $235 / 850$ & $\mathrm{~F} / \mathrm{C}$ \\
\hline \multicolumn{3}{|l|}{ Symplocaceae } \\
\hline Symplocos pubescens & $256 / 829$ & $\mathrm{~F} / \mathrm{C}$ \\
\hline Klotzsch.exBenth. ${ }^{3}$ & & \\
\hline \multicolumn{3}{|l|}{ Tiliaceae } \\
\hline Luehea grandiflora Mart. ${ }^{1}$ & $87 / 331$ & $\mathrm{~F} / \mathrm{C}$ \\
\hline Ulmaceae & & \\
\hline $\begin{array}{l}\text { Celtis pubescens } \\
\text { (Kunth)Spreng. }{ }^{2}\end{array}$ & $246 / 399$ & $\mathrm{~F} / \mathrm{C}$ \\
\hline \multicolumn{3}{|l|}{ Verbenaceae } \\
\hline 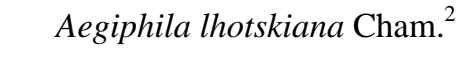 & 540 & $\mathrm{C}$ \\
\hline Aegiphila sellowiana Cham. ${ }^{1}$ & $44 / 329$ & $\mathrm{~F} / \mathrm{C}$ \\
\hline Aloysia virgata Juss. ${ }^{1}$ & $444 / 843$ & $\mathrm{~F} / \mathrm{C}$ \\
\hline Lantana camara L. $^{1}$ & $281 / 695$ & $\mathrm{~F} / \mathrm{C}$ \\
\hline Lantana hypoleuca Briq. ${ }^{2}$ & $637 / 733$ & $\mathrm{~F} / \mathrm{C}$ \\
\hline
\end{tabular}

\section{Vochysiaceae}

\begin{tabular}{lcc} 
Qualea cordata Spreng. $^{2}$ & $186 / 267$ & F/C \\
Qualea $^{2}$ randiflora Mart. & & \\
Qualea $^{2}$ multiflora Mart. & $228 / 852$ & F/C \\
${\text { Vochysia cinnamomea } \text { Pohl }^{2}}^{2}$ & $230 / 851$ & F/C \\
Vochysia tucanorum Mart. $^{2}$ & 391 & C \\
\hline
\end{tabular}

of forest formations occurring along waterways, the numbers varied from 0 to 4 species and were higher in the cerradão (Table 2).

The species characteristic of forest formations found in the different areas of cerrado studied were: Eremanthus erythropappus, Faramea cyanea, Ficus enormis, Inga striata, Leandra aurea, Myrcia breviramis, Ocotea puberula, Psidium cattleyanum, Psychotria velloziana, Qualea jundiahy, Solanum erianthum, Strychnos rubiginosa and Symplocos frondosa. Both Faramea cyanea and Qualea jundiahy occurred in more than one location and, although they were mentioned as occurring in savanna formations only by Mendonça et al. (1998) and Resolução SMA 47/03 (Barbosa, 2004, respectively. Furthermore, $F$. cyanea was mentioned by Mendonça et al. (1998) as a species that also occurs in gallery forests, and $Q$. jundiahy was described by the Resolução SMA 47/03 as a species whose distribution, as for the cerrado biome of São Paulo, was restricted to the central region of the State. Thus, in this work, both 
species were kept within the limited group of species characteristic of the forest formations.

The number of species reported as peculiar to forest formations found in JBMB and in the locations used as a comparison could be higher since many species did not appear in the floristic reports used.

Table 2 - Number of tree and shrub species in different areas (NT); NF - species peculiar to forests (\% in brackets); $\mathrm{NC}$ - seasonal forest species found also in riverine forests. LR - type of survey: $\mathrm{f}$ - floristic; $\mathrm{ft}$ - phytosociological. FS - physiognomies: cs - savanna senso strictu; cd - cerradão

\begin{tabular}{l|c|c|c|c|c}
\hline \multicolumn{1}{c}{ Localities/Sources } & NT & NF & NC $^{\mathbf{1}}$ & LR & FS \\
\hline Bauru, SP (JBMB, this study) & 135 & $6(4,5)$ & 4 & $\mathrm{f}$ & $\mathrm{cd}$ \\
Bauru, SP (Ferracini et al., 1983) & 27 & 0 & 0 & $\mathrm{ft}$ & $\mathrm{cd}$ \\
Corumbataí, SP (Pagano et al., 1989) & 96 & 0 & 0 & $\mathrm{f}$ & $\mathrm{cd}$ \\
Moji-mirim, SP (Toledo Filho et al., 1989) & 104 & 0 & 0 & $\mathrm{ft}$ & $\mathrm{cd}$ \\
Itirapina, SP (Durigan et al., 1994) & 44 & 0 & 0 & $\mathrm{ft}$ & $\mathrm{cs}$ \\
Botucatu, SP (Bicudo et al., 1996) & 58 & $1(1,7)$ & 1 & $\mathrm{f}$ & $\mathrm{cd}$ \\
Agudos, SP (Paschoal and Montanholi, 1997) & 67 & $3(4,5)$ & 2 & $\mathrm{f}$ & $\mathrm{cs}$ \\
Franca, SP (Araújo et al., 1999) & 65 & $2(3,1)$ & 2 & $\mathrm{f}$ & $\mathrm{cd}$ \\
Assis, SP (Durigan et al., 1999) & 154 & $1(0,6)$ & 1 & $\mathrm{f}$ & $\mathrm{cs}$ \\
Assis, SP (Durigan et al., 1999) & 192 & $5(2,6)$ & 4 & $\mathrm{f}$ & $\mathrm{cd}$ \\
S.Rita Passa Quatro, SP (Batalha and Mantovani, 2001) & 114 & $1(1,0)$ & 1 & $\mathrm{f}$ & $\mathrm{cs}$ \\
S.Rita Passa Quatro, SP (Batalha and Mantovani, 2001) & 82 & $1(1,2)$ & 0 & $\mathrm{f}$ & $\mathrm{cd}$ \\
Brotas, SP (Durigan et al., 2001) & 78 & 0 & 0 & $\mathrm{ft}$ & $\mathrm{cs}$ \\
Jaguariaíva, PR (Uhlmann et al., 1998) & 33 & 0 & 0 & $\mathrm{ft}$ & $\mathrm{cs}$ \\
Águas Emendadas, DF (Felfili et al., 1993) & 72 & 0 & 0 & $\mathrm{f}$ & $\mathrm{cs}$ \\
Patrocínio, MG (Felfili et al., 1993) & 68 & 0 & 0 & $\mathrm{f}$ & $\mathrm{cd}$ \\
Uberlândia, MG (Costa and Araújo, 2001) & 76 & 0 & 0 & $\mathrm{ft}$ & $\mathrm{cs}$ \\
Uberlândia, MG (Costa and Araújo, 2001) & 93 & $3(3,2)$ & 3 & $\mathrm{ft}$ & $\mathrm{cd}$ \\
Água Boa, MT (Felfili et al., 2002) & 80 & 0 & 0 & $\mathrm{f}$ & $\mathrm{cs}$ \\
\hline
\end{tabular}

References: ${ }^{1}$ - Rodrigues and Nave (2000); Felfili et al. (2001); Silva Júnior et al. (1998; 2001).

\section{DISCUSSION}

The results involving the families with the highest number of species in the Cerradão of the JBMB did not differ much from those obtained by Rizzini (1971) and Heringer et al. (1977), who analyzed the specific flora composition of savanna formations in Brazil. Out of the 9 families richest in species in the present survey, only Erythroxylaceae, with 5 species in the total, does not appear among the richest in species for the biome cerrado in Brazil, being possibly a local feature of this vegetation in JBMB. Of the 6 species defined as peculiar to forest formations found in the JBMB, i.e., species not peculiar to or accessory to savanna formations, definition based on the terminology presented by Rizzini (1971), only Guapira hirsuta was not found along waterways. This information indicated the importance of the proximity of waterways for a possible occupation of savanna formations by forest species that in regions dominated by cerrados, were restricted to valley bottoms, where forest communities sustained themselves due to higher humidity (Richards, 1996). This hypothesis was corroborated by the results obtained by Gomes et al. (2004), who found that out of the 125 species of their study on a forested savanna located next to a creek, 29 species did not belong to the cerrado. According to the same criteria used in the other works considered in this study, of the total number of species, $13.6 \%$ could be defined as peculiar to forest formations.

Although some of the species found in the JBMB, considered as peculiar or characteristic of savanna formations, e.g., Annona coriacea, Connarus suberosus, Miconia albicans, Qualea grandiflora, Q. multiflora and Vochysia tucanorum (Table 1), were found within the seasonal semi-deciduous forest, their characterization as specialists of savanna phytocenoses should not be questioned. This phenomenon might have happened as a consequence of the expansion of the limits of the seasonal and gallery forests through areas that used to be occupied by forested savanna, after a period without perturbations (Hopkins, 1992; Ratter, 1992). The occurrence of a high number of generalist or ubiquitous species in the savanna 
forest of the JBMB coincided with the observation by Gomes et al. (2004) on the high presence of these species in the cerrados of the State of São Paulo.

As should be expected, due to the favorable microclimatic conditions in the interior of the cerradão, a denser vegetation than cerrado s.s., with lower incidence of light and higher humidity (Eiten, 1972), the occurrence of species peculiar to forest formations was higher in this physiognomy for most of the areas reported. The commonest forest species in the different places studied were Faramea cyanea and Qualea jundiahy, which occurred at 4 different locations. All other species occurred in only one place.

At Uberlândia (Costa and Araújo, 2001), where surveys were carried out in both physiognomies, forest species were only found in the forested savanna. Nevertheless, in Assis (Durigan et al., 1999) and Santa Rita do Passa Quatro (Batalha and Mantovani, 2001), forest species were found in both phytocenoses. In Santa Rita do Passa Quatro, the percentage of forest species was slightly higher in the cerradão, although it is not the dominant physiognomy in that area. The highest percentage of forest species in savanna physiognomies among the works analyzed, 4.5\% (Table 2), was found both in the cerradão of the JBMB and in the cerrado s.s. located in Agudos (Paschoal and Montanholi, 1997). In the case of the JBMB, the proximity of the forest matrix and of a waterway must have influenced this value. Still, in Agudos, since there was a lack of more detailed description of this remnant of cerrado, defining the physiognomy of that fragment as cerrado s.s, in the present work might be improper, as it could actually be cerradão.

The non-occurrence of forest species in the cerradões of some locations could be due to the inclusion criteria adopted, which excluded young tree and shrub individuals in general (Ferracini et al., 1983; Toledo Filho et al., 1989; Durigan et al., 2002; Felfili et al., 2002). Savanna phytocenoses could present a higher frequency of individuals peculiar to small-sized forest formations, because of the competition in an environment distinct from that to which they were adapted. Another possible reason would be their natural inexistence in these areas, a phenomenon favored by the fact they were more distant from forest matrices and waterways, and more isolated (Pagano et al., 1989). The non occurrence of forest species in savanna formations, even when close to waterways, could be caused by fires (Durigan et al., 1994; Uhlmann et al., 1998), and to stronger anthropic action, as it was found in Patrocínio (Felfili et al., 1993).

An indication of the occurrence of plant species uncommon in savanna formations could be found in different works on cerrados, where the authors highlighted the exclusion of these species from their respective studies (Mantovani et al., 1985; Durigan et al., 2003). The small number of common forest species among the different phytocenoses compared and that sheltered savanna remnants, could be a reflection of the high floristic heterogeneity of the cerrado biome (Vieira et al., 2002). Yet another possibility must be considered, i.e., species which could not be characterized as for their habitats of occurrence could belong to the group of species characteristic of forest formations, what would increase the percentage of species of this group in relation to the total of species occurring in the different places analyzed. Still, some of the species defined as characteristic of forest formations could also occur in the savanna in different regions of Brazil, under different ecological conditions.

Although the floristic and phytosociological lists from different locations reported in this study might have suffered interferences of the sampling effort, and of other criteria used in the surveys, the floristic information they contained could indicate probable mechanisms involved in the exchange of floristic elements between savanna and forest phytocenoses (Rizzini, 1971; Heringer et al., 1977) and the colonization of savanna formations by forest species (Hopkins, 1992; Richards, 1996). Such phenomenon that could increase the savanna floristic richness, would include not only generalist species but also many species accessory to the cerrado flora (Rizzini, 1971) and forest species, possible occupiers of savanna formations, especially of forested savanna (Pagano et al., 1989), whose source of propagules could be the contiguous forest matrices (Fernandes, 2000), such as seasonal semi-deciduous and gallery forests.

The occupation of savanna formations by forest species could be explained through the phenomenon of facilitation (Ricklefs, 1993), described by Labouriau (1966), in which generalist tree species, e.g., Copaifera langsdorffii, would act as pioneers in the forest colonization of cerrados, then allowing the posterior occupation by other forest species, since their canopies created a favorable micro-climate (Ricklefs, 1993). Furthermore, many of the arboreal generalist 
species, although not locally abundant as a consequence of their less efficient use of local resources during the competition with specialists (Odum, 1996), would nevertheless be able to occupy the cerrado because of their tolerance to exposure to sun and extreme edaphic conditions (Gottsberger and Morawetz, 1986), in addition to their efficient exploitation of different microhabitats (Begon et al., 1996).

The occurrence of species not peculiar to savanna formations, e.g., Dalbergia frutescens, Inga marginata, Stylogyne ambigua, Guapira hirsuta and others usually sensitive to the action of fire (Richards, 1996) in the interior of the forested savanna of the JBMB, seemed to indicate that this area might undergo secondary succession (Henriques and Hay, 2002). This would facilitate the establishment of forest species nearby the bed of the Vargem Limpa creek (Fig. 1), in places that used to be occupied by seasonal and gallery forest and are currently protected from the action of fires. In the JBMB, the result of the action of fire could be seen in different points of the forest ecotone. The effects of repeated fires had a striking influence on the vegetation complex and provoked the retraction of the seasonal semi-deciduous forest limits, which used to occupy lower topographic heights, throughout the more humid parts of valley bottoms. In places more severely hit by fires, sparse tree and shrub vegetation were encountered, presenting individuals with burnt rhytidome, and abundant herbaceous vegetation, mainly composed by the grasses Andropogon bicornis L., Brachiaria plantaginea (Link) Hichc., Setaria vulpiseta (Lam.) Roem. and Schult., Imperata sp. and Paspalum sp.

Although Ratter (1992) asserted that transitions between seasonal forests and savanna formations were defined by edaphic factors, with fires having little influence, in the JBMB ecotone the action of repeated fires might have exerted strong influence on the definition of the transition between both phytocenoses. Explanations for the abrupt transitions between forest and savanna formations found in some places of the area of study have equally considered edaphic and topographical features and the action of fires (Coutinho, 1990), recurrent and very intense at some times of the history of the JBMB. The edaphic influence should not be despised in the definition of the limits between both phytocenoses, e.g., the level of ground water (Sarmiento, 1996), and higher percentages of clay and silt in relation to the content of sand in lower heights of the terrain that would retain water for longer periods of time. The higher humidity would favor the occupation of the valley bottoms by forest formations in areas of savanna (Eiten, 1972; Leitão Filho, 1982).

The results of the present work seemed to corroborate the hypothesis of the floristic influence of hygrophilous and generalist forest species in the cerrados (Ab'Sáber, 2003). In addition, the riverine or gallery forests, which were extensions of the Atlantic and Amazonian forest formations in the interior of the cerrado (Rizzini, 1997) could act as access paths for generalist species of forest origin, e.g., Casearia sylvestris, Protium heptaphyllum and Tapirira guianensis (Oliveira Filho and Ratter, 2000), supposedly indifferent to variations of the edaphic humidity, luminosity and temperature degrees (Walter and Ribeiro, 1997). These species would contribute to the floristic composition of savanna formations. In areas free from the action of fires, they would facilitate the colonization of cerrados by different forest species. This phenomenon could be related to the expansion of forest remnants in places protected from the action of fires (Hopkins, 1992; Ratter, 1992). Together with the major proximity of forest remnants (Ribeiro and Tabarelli, 2002) in areas with low incidence of fires, it would favor the establishment and development of propagules of a higher richness of species, especially those sensitive to the action of fire (Henriques and Hay, 2002).

Some tree species found in the area of study, such as Dendropanax cuneatum, Tabebuia aurea and Terminalia glabrescens, were not mentioned by Leitão Filho (1992) among the tree species of the cerrados of the State of São Paulo, and should be considered as an addition to his survey. Other species found in the different works used as comparisons were not present in the floristic reports used as a reference, which reinforces the need to update these floristic lists. The occurrence of species peculiar to or characteristic of forest formations in savanna phytocenoses could represent an important mechanism of occupation of the cerrados by species not tolerant to fire, when this factor was suppressed (Jeltsch et al., 2000). 


\section{RESUMO}

A heterogeneidade florística do cerrado pode sofrer influência de espécies florestais oriundas de matrizes vegetacionais próximas, sendo as matas de galeria uma das vias para essa ocupação. A expansão florestal por áreas savânicas pode ser explicada por tal fenômeno. As espécies arbustivoarbóreas presentes na área estudada, na cidade de Bauru, Estado de São Paulo, e em 14 diferentes localidades abrigando cerrado sensu stricto e cerradão, foram definidas como florestais a partir de listagens florísticas das fitocenoses em questão. As porcentagens de ocorrência de espécies florestais nas localidades analisadas variaram de zero a 4,5\%. A proximidade de matrizes florestais, a ocorrência de incêndios e critérios de inclusão utilizados foram alguns dos fatores que podem ter influenciado tal variação.

\section{ACKNOWLEDGEMENTS}

We thank to the Post-Graduation Program in Plant Biology of the Universidade Estadual de Campinas and to $\mathrm{CNPq}$ for the Master's grant awarded to M.H.O. Pinheiro. We also thank the constant support offered by the Municipal Botanical Garden of Bauru (JBMB) and to Dr. Giselda Durigan for her suggestions on the first version of the paper.

\section{REFERENCES}

Ab'Saber, A. N. (2003), Os domínios de natureza no Brasil: potencialidades paisagísticas. São Paulo: Ateliê Editorial.

Araújo, A. R. B.; Teixeira, M. I. J. G. and Rodrigues, R. R. (1999), Florística e fitossociologia de um trecho de cerrado no município de Franca. Naturalia, 24, 153-170.

Barbosa, L. M. (2004), Resolução SMA 47 (26/11/2003) da Secretaria de Meio Ambiente de São Paulo e a normatização de processos de recuperação de áreas degradadas. São Paulo: Secretaria de Meio Ambiente.

Batalha, M. A. and Mantovani, W. (2001), Floristic composition of the cerrado in the Pé-de-gigante Reserve (Santa Rita do Passa Quatro, Southeastern Brazil). Acta Bot. Bras., 15, 289-304.

Bauru. (1997), Plano Diretor de Bauru 1996: Cadernos de Dados, Levantamentos, Diagnósticos, Lei $\mathrm{n}^{\circ}$ 4126/1996. Bauru: Prefeitura Municipal de Bauru, Secretaria Municipal do Planejamento.
Begon, M.; Harper, J. L. and Townsend, C. R. (1996), Ecology: individuals, populations and communities. Oxford: Blackwell Science.

Bicudo, L. R. H.; Cesar, O. and Monteiro, R. (1996), Florística comparativa de uma área de cerrado no município de Botucatu, SP (Basil). Arq. Biol. Tecnol., 39, 685-691.

Braithwaite, R. W. (1996), Biodiversity and fire in the savanna landscape. In: Solbrig, O.; Medina, E. and Silva, I. F. (Eds.). Biodiversity and savanna ecosystem processes: a global perspective. Berlin: Springer. pp. 121-140.

Castro, A. A. J. F.; Martins, F. R.; Tamashiro, J. Y. and Shepherd, G. J. (1999), How rich is the flora of Brazilian cerradão. Ann. Miss. Bot. Gard., 86, 192-224.

Cavassan, O. (2002), O cerrado do Estado de São Paulo. In: Klein, A. L. (Org.). Eugen Warming e o cerrado brasileiro: um século depois. São Paulo: UNESP. pp. 93-106.

Costa, A. A. and Araújo, G. M. (2001), Comparação da vegetação arbórea de cerradão e de cerrado na reserva do Panga, Uberlândia, Minas Gerais. Acta Bot. Bras., 15, 63-72.

Coutinho, L. M. (1978), O conceito de cerrado. Rev. Bras. Bot., 1, 17-23.

Coutinho, L. M. (1990), Fire in the ecology of the Brazilian cerrado. In: Goldammer, J. G. (Ed.). Fire in the tropical biota. Berlin: Springer-Verlag. pp. 81-105.

Durigan, G.; Bacic, M. C.; Franco, G. A. D. C.; Siqueira, M. F. (1999), Inventário florístico do cerrado na Estação Ecológica de Assis. Hoehnea, 26, 149-172.

Durigan, G.; Baitello, J. B.; Franco, G. A. D. C. and Siqueira, M. F. (2004), Plantas do cerrado paulista: imagens de uma paisagem ameaçada. São Paulo: Páginas and Letras.

Durigan, G.; Leitão Filho, H. F. and Rodrigues, R. R. (1994), Phytosociology and structure of a frequently burnt cerrado vegetation in SE-Brazil. Flora, 189, 153-160.

Durigan, G.; Nishikawa, D. L. L.; Rocha, E.; Silveira, E. R. S.; Pulitano, F. M.; Regalado, L. B.; Carvalhaes, M. A.; Paranaguá, P. A. and Ranieri, V. E. L. (2002), Caracterização de dois estratos da vegetação em uma área de cerrado no município de Brotas, SP, Brasil. Acta Bot. Bras., 16, 251-262.

Durigan, G.; Ratter, J. A.; Bridgwater, S.; Siqueira, M. F. and Franco, G. A. D. C. (2003), Padrões fitogeográficos do cerrado paulista sob uma perspectiva regional. Hoehnea, 30, 39-51.

Eiten, G. (1972), The cerrado vegetation of Brazil. Bot. Rev., 38, 201-341.

Felfili, J. M.; Nogueira, P. E.; Silva Jr., M. C.; Marion, B. S. and Delitti, W. B. C. (2002), Composição florística e fitossociológica do cerrado sentido restrito no município de Água Boa - MT. Acta Bot. Bras., 16, 103-112. 
Felfili, J. M.; Mendonça, R. C.; Walter, B. M. T.; Silva Júnior, M. C.; Fagg, C. W.; Nóbrega, M. G. G.; Sevilha, A. C. and Silva, M. A. (2001), Flora fanerogâmica das matas de galeria e ciliares do Brasil Central. In: Ribeiro, J. F.; Fonseca, C. E. L. and Sousa-Silva, J. C. (Eds.). Cerrado: caracterização e recuperação de Matas de Galeria. Planaltina: EMBRAPA. pp. 195-263.

Felfili, J. M.; Silva Jr., M. C.; Rezende, A. V.; Machado, J. W. B.; Walter, B. M. T.; Silva, P. E. N. and Hay, J. D. (1993), Análise comparativa da florística e fitossociologia da vegetação arbórea do cerrado Sensu Stricto na Chapada Pratinha, DF Brasil. Acta Bot. Bras., 6, 27-46.

Fernandes, A. (2000), Fitogeografia brasileira. Fortaleza: Multigraf.

Ferracini, M. C.; Ferlini, R. F. and Cavassan, O. (1983), Composição florística de uma área de cerrado no município de Bauru, SP. Salusvita, 2, 1-9.

Gomes, B. Z.; Martins, F. R. and Tamashiro, J. Y. (2004), Estrutura do cerradão e da transição entre cerradão e floresta paludícula num fragmento da International Paper do Brasil Ltda., em Brotas, SP. Rev. Bras. Bot., 27, 249-262.

Goodland, R. J. A. (1970), Plants of the cerradão vegetation of Brazil. Phytologia, 20, 57-79.

Gottsberger, G. and Morawetz, W. (1986), Floristic, structural and phytogeographical analysis of the savannas of Humaitá (Amazonas). Flora, 178, 41-71.

Henriques, R. P. B. and Hay, J. D. (2002), Patterns and dynamics of plant populations. In: Oliveira, P. S. and Marquis, R. J. (Eds.). The cerrados of Brazil: ecology and natural history of a neotropical savanna. New York: Columbia University Press. pp. 140-158.

Heringer, E. P.; Barroso, G. M.; Rizzo, I. A. and Rizzini, C. T. (1977), A flora do cerrado. In: Ferri, M. G. (Coord.). Simpósio sobre o cerrado: bases para a utilização agropecuária. São Paulo: EDUSP. pp. 211-232.

Hopkins, B. (1992), Ecological process at the forestsavanna boundary. In: Furley, P. A.; Proctor, J. and Ratter, J. A. (Eds.). Nature and dynamics of forestsavanna boundaries. London: Chapman and Hall. pp. 21-33.

Jeltsch, F.; Weber, G. E. and Grimm, V. (2000), Ecological buffering mechanisms in savannas: a unifying theory of long-term tree-grass coexistence. Plant Ecology, 161, 161-171.

Labouriau, L. G. (1966), Revisão da situação da ecologia vegetal dos cerrados. Anais Acad. Bras. Ciênc., 38, 5-38.

Leitão Filho, H. F. (1982), Aspectos taxonômicos das florestas do Estado de São Paulo. In: Congresso Nacional sobre Essências Nativas, Campos do Jordão. Anais ... Campos do Jordão

Leitão Filho, H. F. (1992), A flora arbórea dos cerrados do estado de São Paulo. Hoehnea, 19, 151-163.
Mantovani, W.; Leitão Filho, H. F. and Martins, F. R. (1985), Chave baseada em caracteres vegetativos para identificação de espécies lenhosas da Reserva Biológica de Moji Guaçú, SP. Hoehnea, 12, 35-66.

Méio, B. B.; Freitas, C. V.; Jatobá, L.; Silva, M. E. F.; Ribeiro, J. F. and Henriques, R. P. B. (2003), Influência da flora das florestas amazônica e atlântica na vegetação do cerrado sensu stricto. Rev. Bras. Bot., 26, 437-444.

Mendonça, R.; Felfili, J. M.; Walter, B. M. T.; Silva Junior, M. C.; Rezende, A. V.; Filgueiras, T. S. and Nogueira, P. E. (1998), Flora vascular do cerrado. In: Sano, S. M. and Almeida, S. P. (Eds.). Cerrado: ambiente e flora. Planaltina: EMBRAPA. pp. 287-556.

Miranda, H. S.; Bustamante, M. M. C. and Miranda, A. C. (2002), The fire factor. In: Oliveira, P. S. and Marquis, R. J. (Eds.). The cerrados of Brazil: ecology and natural history of a neotropical savanna. New York: Columbia University Press. pp. 51-68.

Odum, E. (1996), Ecology: a bridge between science and society. Sunderland: Sinauer Associates.

Oliveira Filho, A. T. and Ratter, J. A. (2000), Padrões florísticos das matas ciliares da região do cerrado e a evolução das paisagens do Brasil Central durante o Quaternário Tardio. In: Rodrigues, R. R. and Leitão Filho, H. F. (Eds.). Matas ciliares: conservação e recuperação. São Paulo: Universidade de São Paulo; FAPESP. pp. 73-89.

Oliveira Filho, A. T. and Ratter, J. A. (2002), Vegetation physiognomies and woody flora of the cerrado Biome. In: Oliveira, P. S. and Marquis, R. J. (Eds.). The cerrados of Brazil: ecology and natural history of a neotropical savanna. New York: Columbia University Press. pp. 91-120.

Pagano, S. N.; César, O. and Leitão Filho, H. F. (1989), Composição florística do estrato arbustivo-arbóreo da vegetação de cerrado da área de proteção ambiental (APA) de Corumbataí - Estado de São Paulo. Rev. Brasil. Biol., 49, 37-48.

Paschoal, M. E. S. and Montanholi, R. (1997), Levantamento florístico do estrato arbustivo-arbóreo de um fragmento de vegetação nativa no campo experimental USC, Agudos-SP. Salusvita, 16, 161-174.

Pinheiro, M. H. O. (2000), Levantamento florístico e fitossociológico da floresta estacional semidecidual do Jardim Botânico Municipal de Bauru, São Paulo. Dissertação (Mestrado) - Universidade Estadual de Campinas, Campinas.

Pinheiro, M. H. O.; Monteiro, R. and Cesar, O. (2002), Levantamento fitossociológico da floresta estacional semidecidual do Jardim Botânico Municipal de Bauru, São Paulo. Naturalia, 27, 145-164.

Ratter, J. A. (1992), Transitions between cerrado and forest vegetation in Brazil. In: Furley, P. A.; Proctor, J. and Ratter, J. A. (Eds.). Nature and dynamics of forest-savanna boundaries. London: Chapman and Hall. pp. 417-429. 
Ratter, J. A.; Bridgewater, S.; Ribeiro, J. F.; Dias, T. A. B. and Silva, M. R. D. A. (2000), Estudo preliminar da distribuição das espécies lenhosas da fitofisionomia cerrado sentido restrito nos estados compreendidos pelo Bioma cerrado. Bol. Herb. Ezechias Paulo Heringer, 5, 5-43.

Ratter, J. A.; Bridgewater, S. and Ribeiro, J. F. (2003), Analysis of the floristic composition of Brazilian cerradão vegetation III: comparison of the woody vegetation of 376 areas. Edinburgh J. Bot., 60, 57-109.

Ribeiro L. F. and Tabarelli, M. (2002), A structural gradient in cerrado vegetation of Brazil: changes in woody plant density, species richness, life history and plant composition. J. Trop. Ecol., 18, 775-794.

Richards, P. W. (1996), The tropical rain forest: an ecological study. Cambridge: Cambridge University Press.

Ricklefs, R. E. (1993), A economia da natureza: um livro-texto em ecologia básica. Rio de Janeiro: Guanabara Koogan.

Rizzini, C. T. (1971), A flora do cerrado: análise florística das savanas centrais. In: Ferri, M. G. (Coord.). Simpósio sobre o cerrado. São Paulo: EDUSP. pp. 107-153.

Rizzini, C. T. (1997), Tratado de fitogeografia do Brasil: aspectos ecológicos, sociológicos e florísticos. Rio de Janeiro: Âmbito Cultural.

Rodrigues, R. R. and Nave, A. G. (2000), Heterogeneidade florística das matas ciliares. In: Rodrigues, R. R. and Leitão Filho, H. F. (Eds.). Matas ciliares: conservação e recuperação. São Paulo. pp. 45-71.

Sarmiento, G. (1996), Biodiversity and water relations in tropical savannas. In: Solbrig, O.; Medina, E. and Silva, I. F. (Eds.). Biodiversity and savanna ecosystem processes: a global perspective. Berlin: Springer. pp. 61-75.

Silberbauer-Gottsberger, I. and Gottsberger, G. (1984), Cerrado-cerradão: a comparison with respect to number of species and growth forms. Phytocoenologia, 12, 293-303.

Silberbauer-Gottsberger, I.; Morawetz, W. and Gottsberger, G. (1977), Frost damage of cerrado plants in Botucatu, Brazil, as related to the geographical distribution of the species. Biotropica, 9, 253-261.

Silva Jr., M. C.; Felfili, J. M.; Nogueira, P. E. and Rezende, A. V. (1998), Análise florística das matas de galeria no Distrito Federal. In: Ribeiro, J. F. (Ed.). Cerrado: matas de galeria. Planaltina: EMBRAPA. pp. 53-84.
Silva Jr., M. C.; Felfili, J. M.; Walter, B. M. T.; Nogueira, P. E.; Resende, A. V.; Moraes, R. O. and Nóbrega, M. G. G. (2001), Análise da flora arbórea de matas de galeria no Distrito Federal: 21 levantamentos. In: Ribeiro, J. F.; Fonseca, C. E. L. and Sousa-Silva, J. C. (Eds.). Cerrado: caracterização e recuperação de matas de galeria. Planaltina: EMBRAPA. pp. 143-185.

Toledo Filho, D. V.; Leitão Filho, H. F. and Shepherd G. J. (1989), Estrutura fitossociológica da vegetação de cerrado em Moji-Mirim (SP). Rev. Inst. Florest., 1, $1-12$.

Uhlmann, A.; Galvão, F. and Silva, S. M. (1998), Análise da estrutura de duas unidades fitofisionômicas de savana (cerrado) no sul do Brasil. Acta Bot. Bras., 12, 231-247.

Veloso, H. P. (1992), Sistema fitogeográfico. In: Manual técnico da vegetação brasileira. Rio de Janeiro: Fundação Instituto Brasileiro de Geografia e Estatística. pp. 9-38.

Vieira, D. L. M.; Aquino, F. G.; Brito, M. A.; Fernandes-Bulhões, C. and Henriques, R. P. B. (2002), Síndromes de dispersão de espécies arbustivo-arbóreas em cerrado sensu stricto do Brasil Central e savanas amazônica. Rev. Bras. Bot., 25, 215-220.

Walter, B. M. T. and Ribeiro, J. F. (1997), Spatial floristic patterns in gallery forests in the cerrado region, Brazil. In: International Symposium on Assessment and Monitoring of Forests in Tropical Dry Regions with Special Reference to Gallery Forests, Brasília. Proceedings ... Brasília.

Received: January 28, 2005; Revised: August 10, 2005; Accepted: April 10, 2006. 